\title{
Access to Improved Sanitation in Informal Settlements: The Case of Dar es Salaam City, Tanzania
}

\author{
Samson Elisha Kasala, Marco Mathias Burra, Tumpale Sakijege Mwankenja \\ Department of Urban and Regional Planning, Ardhi University, Dar es Salaam, Tanzania \\ Email: samson.kasala@gmail.com
}

Received 8 January 2016; accepted 8 March 2016; published 11 March 2016

Copyright $(\underset{2016}{ }$ by authors and Scientific Research Publishing Inc.

This work is licensed under the Creative Commons Attribution International License (CC BY). http://creativecommons.org/licenses/by/4.0/

(c) (i) Open Access

\begin{abstract}
A large number of people in developing countries live in informal settlements. Such settlements are mostly situated in areas that are frequently flooded. In terms of sanitation, majority informal settlements dwellers use traditional pit latrine technology, which is considered cheap given their level of income. The use of pit latrines in areas that are frequently flooded causes health risks. Most of the informal settlements lack access to infrastructure services particularly sanitation facilities. This has made many residents discharge waste water from pit latrines into storm water run-offs. This often leads to environmental pollution and endangers the health of local residents. Based on the current study, this paper attempts to examine how and the extent to which residents in these informal settlements get access to improved sanitation. The paper also draws lessons to inform the way forward. The findings show that community based initiatives, partnerships and law enforcement are instrumental in improving access to sanitation in informal settlements.
\end{abstract}

\section{Keywords}

Informal Settlements, Sanitation, Pit Latrine, Community, Partnerships

\section{Introduction}

Informal settlements have become a common feature in cities of developing countries and a lot has been written about them. On the positive side, informal settlements minimize house demands (Sheuya, 2004; Kibue, 2007) and create informal employment through, inter alia, house extensions and related income generating activities (Sinai, 1998; Ghafur, 2001). On the negative side informal settlements represent potential risks to residents' health and the environment. In most cities of developing countries, informal settlements may be identified by the 
following characteristics: 1) they are located in areas that are prone to various hazards (UN-Habitat, 2009); 2) they are confronted by uncoordinated urban development (Dubovyk, Sliuzas, \& Flacke, 2010); 3) they lack functioning infrastructures in terms of sewerage system, drainage channels, roads and solid waste disposal mechanisms; 4) they lack improved sanitation.

Available research shows that, about 2.5 billion people lack access to basic sanitation services. A large proportion of urban residents lacking improved sanitation, live in informal settlements (UNICEF/WHO, 2012). By all aspects, the negative characteristics of informal settlements outweigh the positive ones. This situation poses potential risks to residents' health and livelihood activities. Thus consulted efforts are needed to reduce the negativities and, improving access to sanitation is just one of such efforts.

In recent years, a number of initiatives have been put in place to minimize the negative characteristics commonly perceived as problems facing people living in informal settlements. Effort to increase the number of people with access to improved sanitation is an example of initiatives undertaken to improve sanitation systems in informal settlements. This paper provides a detail analysis of sanitation improvement initiatives and community responses towards those initiatives. The paper is based on empirical investigations in the informal settlements of Keko Machungwa and Maguruwe in Dar es Salaam city, Tanzania.

\section{Sanitation and the Challenges}

Sanitation is a wide ranging concept that covers general cleanliness ranging from safe removal, collection, storage, transportation and disposal of both solid and liquid waste, be it from home or industries. However, to many people when considering sanitation, the first thing that comes to their mind is a latrine. In reality the term sanitation goes beyond a latrine.

"Sanitation generally refers to the provision of facilities and services for the safe disposal of human urine and feaces... The word 'sanitation' also refers to the maintenance of hygienic conditions, through services such as garbage collection and wastewater disposal” (WHO, 2014). Also Evans (2005) listed elements encompassing sanitation and hygiene to include: Safe collection, treatment and disposal of human excreta (feaces and urine), management of solid waste, drainage and disposal of waste water, and drainage of storm water, to mention but a few. The two definitions highlighted above imply that, when considering improved sanitation, one has to also consider all the things that may cause unsanitary conditions in a given locality.

Until 2015, improving access to sanitation wasone of the critical issuesbeing addressed under Millennium Development Goals (MDGs). MDG 7, Target 10, states that "halve, by 2015, the proportion of people without sustainable access to safe drinking water and basic sanitation. However, a report by UNICEF and World Health Organisation-WHO (UN-Habitat (2013) shows that, about 2.5 billion people in the world lack access to basic sanitation services. This indicates that the world is far from meeting MGD 7, Target 10 in 2015. The report by UNICEF \& WHO (UN-Habitat, 2013) cautions "If current trends continue, these numbers will remain unacceptably high by the end of 2015”.

What efforts have been made so far to deliver improved sanitation? There are several sanitation improvement programmes that have been or are being implemented in different countries. In Ghana for example, a GH-GAMA Sanitation and Water Project is being implemented. The project aims at increasing access to improved sanitation and improved water supply. It focuses on low income communities in the Greater Accra Metropolitan AreaGAMA (Bengoechea, 2013). A Global Sanitation Fund (GSF) is being implemented in Nepal with objectives to achieve open defecation free status and adopt good hygiene practices (UN-Habitat, 2013).

Although many developing countries have attempted to initiate programs geared towards having improved sanitation to its local people, sanitation situations in informal settlements are still unaccepably poor. In the rural areas of Tanzania, Ethiopia and Sudan for example, 93\%, 81\% and 76\% of people respectively, have no access to improved sanitation. Similarly, less than $50 \%$ of urban population in most of the developing countries (like Kenya, Mali, Liberia) lack access to basic sanitation (Table 1).

As revealed in Table 1, a large number of people in developing countries lack improved sanitation. Some of the challenges reported to contribute to such a situation include: high rates of population growth without expansion of public services, short supply of skilled personnel, low political commitment, financial constraints, and lack of context specific technology (Okonkwo, 2010). Lack of improved sanitation is directly related to eruption of water-borne diseases. The World Health Organisaton (WHO, 2014) has revealed, based on 2012 figures, that diarrhea is one of the top ten leading diseases in cities of sub saharan Africa. Available research knowledge 
Table 1. Status of access to improved sanitation for urban and rural populations in selected countries.

\begin{tabular}{ccccc}
\hline & \multicolumn{2}{c}{$\begin{array}{c}\text { Population with access to improved } \\
\text { sanitation (figures in \%) }\end{array}$} & $\begin{array}{c}\text { Population without access to improved } \\
\text { sanitation (figures in \%) }\end{array}$ \\
\cline { 2 - 5 } & Urban & Rural & Urban & Rural \\
\hline Tanzania & 20 & 7 & 80 & 93 \\
Ethiopia & 29 & 19 & 71 & 81 \\
Sudan & 44 & 14 & 56 & 86 \\
Ghana & 19 & 8 & 81 & 92 \\
Kenya & 32 & 32 & 68 & 68 \\
Mali & 35 & 14 & 65 & 86 \\
Liberia & 29 & 7 & 71 & 93 \\
\hline
\end{tabular}

Source: UNICEF \& WHO (2012).

indicates that children are the most affected group. According to UNDP (2006), and UNICEF/WHO (2009) diarrhea remains the second leading cause of death among children under five globally. This means that many diseases caused by poor hygiene will be reduced once sanitation is improved.

So far, a lothas been written aboutsanitation locally and internationally, but there is inadequate information necessary in addressingsanitation issues at the local level. The local level in this case, is an informal settlement. In light of that, this paper attempts to investigate how and the extent to which residents in informal settlements of Keko Machungwa and Maguruwe get access to improved sanitation, and draw lessons to inform the way forward. Specific question posed include:

- What are the existing latrine types?

- Are there initiatives to increase access to improved sanitation (latrine) and to what extent?

- What is the community response towards attaining improved sanitation (latrine)?

- What efforts are being made to attain improved sanitation in line with improved latrine?

- What policy measures are needed to promote improved sanitation?

\section{Sanitation in Dar es Salaam: Background}

Dar es Salaam is Tanzanians' largest city and the main commercial and industrial centre. According to the 2012 Census, Dar es Salaam City has a population of 4.36 million, accounting for 10 percent of the total population in Tanzania (URT, 2013). Available research indicates that about $80 \%$ of Dar es Salaam population lives in informal settlements (Kyessi \& Sakijege, 2013). Sanitation provision together with other public services like waste collection and disposal are still poor in Dar es Salaam. The situation is worse in informal settlements, where unsanitary conditionsare a common feature (UCLAS, 2004). Existence of unsanitary conditions in informal settlementswhere about $80 \%$ of the the City population lives, implies that, a large number of people in Dar es Salaam live in a health vulnerable environment.

The most dominant sanitation system in informal settlementsof Dar es Salaam is traditional pit latrines. Available research knowledge provides that over 90\% of the population in Tanzania urban areas depends on pit latrines (UCLAS, 2004). Sakijege et al. (2014) notes that, poor people in urban areas are pushed into locations that lack sanitation facilities and are prone to natural hazards particularly flooding. Recharge of groundwater which raises water table is a common situation in informal settlements located in flooding areas.This condition causes overflow of pit latrines and thus sanitation is adversely affected. Available research evidence in some informal settlements (e.g. Keko Machungwa, Ukonga and Majumba sita) indicates that groundwater ${ }^{1}$ especially shallow wells are polluted (UCLAS, 2014; Kimani \& Ngindu, 2007; Sakijege, Lupala, \& Sheuya, 2012). Besides, laboratory test, water pollution levels documented by Sakijege, Lupala and Sheuya (2012) revealed pres-

${ }^{1}$ Kimani-Murage \& Ngindu (2007) reported that "majority of the urban poor draw domestic water from nearby wells. Overcrowding in informal settlements limits attaining the required distance between wells and pit latrines. As a result micro-organisms migrate from latrines into water sources". 
ence of Feacal coliforms. This implies that, unless sanitation system in informal settlements is improved, residents in these settlements may suffer from diseases such as typhoid and cholera, as some of the feacal coliform bacteria are pathogenic to humans (Ecology's Water Quality Program, 2005).

Who is responsible for provision of sanitation services? Immediately after independence water and sanitation services were provided for free to poor people and minimal charges were imposed to residents in high-income neighborhoods. Water and sanitation services were guided by socialism under the government ministry (UCLAS, 2004). The aim was to achieve fair distribution of wealth. Provision of water and sanitation services for free and at a low cost came to demise because the funds recovered were not enough to meet operation and maintenance costs.

As soon as operations of water and sanitation services became problematic, Tanzanian Government established Urban Water and Sewer Authorities (UWSAs). In Dar es Salaam City, a Dar es Salaam Water supply and Sanitation Authority (DAWASA) was established (Kjellen, 2006). Despite these reforms the provision of water and sanitation services by DAWASA still couldn't meet Dar es Salaam City's population demands effectively. As a result DAWASA was privatized in 2003, and City Water Services (CWS) Ltd took over through a competitive tendering process. The privatization of DAWASA was aimed at puting; inter alia, operational risk on CWS and capital risk on DAWASA (Kjellen, 2006). City Water Services Ltd was accused of poor performance and acting against the agreed terms of contract, CWS Ltd was then terminated by the Government in 2005. After termination, Dar es Salaam Water and Sewerage Corporation (DAWASCO) was established (Kjellen, 2006). DAWASCO was therefore responsible for, among other things, increasing water supply and sewerage system coverage and revenue collection.

With these reforms, slight improvements are evident to date but mostly in planned areas and the Dar es Salaam City's Central Business District. It is in the planned settlements where only about $4 \%$ of the city residents are served by existing sewerage system (URT, 2009). This comes from the fact that, the available central sewerage system covers $188 \mathrm{~km}$ of sewers. The areas covered by the system include: central business district (CBD), Kariakoo, Msasani, Mwenge and Ubungo industrial area (UCLAS, 2004). The lower coverage of the central sewerage system indicates that sanitation in Dar es Salaam is an issue which needs immediate intervention. This means, more consulted efforts need to focuss on informal settlements where majority (80\%) of the Dar es Salaam City's people reside and use pit latrine as a dominant sanitation system.

\section{Methodology}

Two informal settlements were selected for empirical study. The settlements included Keko Machungwa with 16,456 people and located about $3 \mathrm{~km}$ from the central business district. Maguruwe with 7460 people and located $5 \mathrm{~km}$ away from the centre of the City. Keko Machungwa and Maguruwe were selected on the basis of 1) convenience i.e. they are located close to the city centre, 2) they are typical and among the oldest informal settlements, 3) large number of people in those settlements use traditional pit latrines, and thus intervention is needed and 4) they are information rich cases.

The two informal settlements although they poses all the characteristics of informal settlements they are not the same. They are not the same in the manner that Keko Machungwa has a strong organisation namely "Tumaini Letu" which is involved in sanitation improvement initiatives. The organisation has members from within Keko Machungwa and each member contributes a token amount of money per month to strengthen its fund. Also, the organisation is supported financially and technically by a local NGO namely Center for Community Initiative (CCI). Members and non-members get loans from the organisation's fund for improving their latrines. Details related to the loans, success and failureexperiencesare discussed in this paper. On the other hand Maguruwe informal settlement has no such an organisation to spearhead sanitation improvement efforts. In that regard, Keko Machungwa is a bit advanced than Maguruwe in terms of organiation and sanitation improvement initiatives.

Observation, official interviews, household interviews and photography were the key data collection techniques used. The interview involved $30^{2}$ respondents in each case, $2^{3}$ local officials in each settlement and $1^{4}$ person engaged in cesspit emptier truck business. The following methodological procedure was used to choose

\footnotetext{
${ }^{2}$ In Keko Machungwa 15 respondents improved their latrines, the other 15 did not.

${ }^{3}$ In Maguruwe the 2 officials were interviewed. These were from the Local Authority. In Keko Machungwa 1 official from Tumaini Letu Organisation was interviewed. The other came from the Local Authority.

${ }^{4}$ Was engaged to confirm the price charged to cesspit emptier truck users.
} 
respondents.

1) In Keko Machungwa the procedure involved selecting 15 respondents who had improved their latrines. Specifically the procedure entailed:

- Obtaining the list of local residents ${ }^{5}$ (heads of households) who had improved their latrines,

- Selecting 15 respondents randomly using the random table.

2) Selecting 15 respondents who did not improve their latrines in Keko Machungwa and such 30 respondents in Maguruwe settlement. Specifically the procedure entailed:

- Obtaining a list of heads of household for Keko Machungwa and Maguruwe from a voters' list ${ }^{6}$,

- Selecting $15^{7}$ respondents in Keko Machungwa and 30 respondents in Maguruwe using arandom table.

\section{Latrine Types, Existing Initiatives and Community Response towards Improved Sanitation}

This section presents a discussion of the existing latrine types, initiatives to improve access to improved latrines, and the extent to which community gets improved latrines. Community response towards improved latrines and other efforts made to attain improved sanitation are also discussedin addition to latrines.

\subsection{Keko Machungwa}

\subsubsection{Existing Latrine Types}

As is the case in many of the informal settlements in Dar es Salaam City, most people in Keko Machungwa are classified as low or medium income earners. Major types of latrines used are traditional pit latrines. A mapping project conducted by CCI in 2012 in collaboration with Keko Machungwa federation (PHAST ujenzi) revealed that a large number of people (49\%) in the settlement use traditional pit latrines (Table 2).

In a discussion with a chairman of Tumaini Letu Organisation (TLO), it was revealed that sanitation conditions in Keko Machungwa are very poor and people resorted to the use of hygienically unacceptable latrines. In view of that, the community is implementing a sanitation improvement program. Given the limited financial resources available, the program has started with toilets that are in extremely poor conditions.

Despite the efforts made by CCI through PHAST ujenzi as shall be discussed later, sanitation situation in Keko Machungwa informal settlement is still poor. The sanitation situation observed in Keko Machungwa underscores the case in point. Through field observations it was revealed that, there are people who have poor toilets that are extremely risky to users and the environment in general (Figure 1(a)). The situation becomes worse during rainy seasons, when many toilets get flooded. Field observations revealed that 2 out of 15 respondents were found to discharge raw waste from their toilets directly into a nearby stream (Figure 1(b)).

\subsubsection{Initiatives and Extent to Increase Access to Improved Sanitation (Latrine)}

In Keko Machungwa an Organisation called Tumaini Letu exists. The organisation is involved in sanitation improvement initiatives in partnership with $\mathrm{CCI}^{8}$. As part of its efforts to contribute to improving sanitation, CCI and Tumaini Letu Organisation (TLO) conducted, in 2012, a study in Keko Machungwa under the auspices of Temeke Municipal Council, a Local Authority of the area. The study was aimed at, inter alia, exploring environmental problems affecting the settlement. Through that study, a number of issues were identified for the purpose of addressing them. The issues identified included: poor toilets, poor solid waste management, lack of clean and safe water, to mention but a few. In implementing its activities, CCI works with local communities. In this case, TLO worked with CCI as a representative of the local community in Keko Machungwa. In that regard, CCI supported the TLO to initiate a Participatory Hygiene and Sanitation Transformation (PHAST) program. The program was aimed at awareness creation, mobilizing funds for cleaning river streams and facilitating construction of toilets. The CCI's support extended to TLO for the PHAST program was in terms of funds and training on low cost sanitation options.

In addition to financial and training support from CCI each member of TLO was supposed to contribute Tshs 500 per month. This money was planned to be used as loans for constructing improved toilets. The loans

\footnotetext{
${ }^{5}$ Until July, 2014 when the study was conducted about 34 households had managed to improve their latrine.

${ }^{6}$ It should be noted that recently (2012) Tanzania conducted a census survey.

${ }^{7}$ Before selection, names of the 15 respondents who were identified tohave improved latrines were eliminated.

${ }^{8} \mathrm{CCI}$ stands for Centre for Community Initiative. It is a non-governmental organization.
} 
Table 2. Existing types of latrines in Keko Machungwa.

\begin{tabular}{cccc}
\hline S/No. & Type of toilets & Number of toilets & Percentage \\
\hline 1 & Traditional pit latrine & 492 & 49.34 \\
2 & Pour flash direct pit & 85 & 8.50 \\
3 & Pour flash offset & 379 & 38.01 \\
4 & Tire pit latrine & 4 & 0.45 \\
5 & Septic tank & 37 & 3.70 \\
& Total & 997 & 100 \\
\hline
\end{tabular}

Source: CCI.

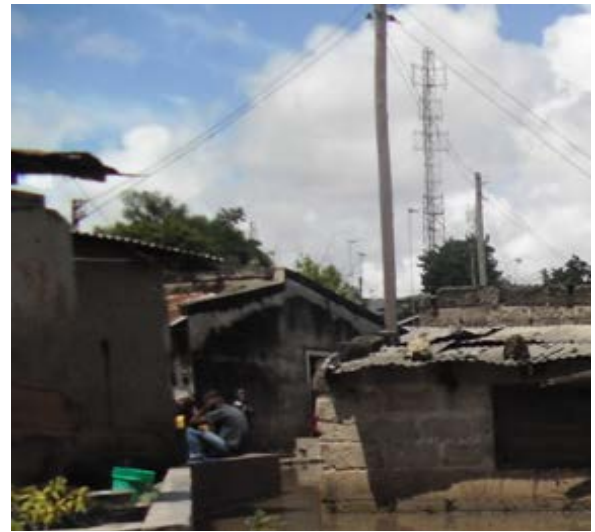

(a)

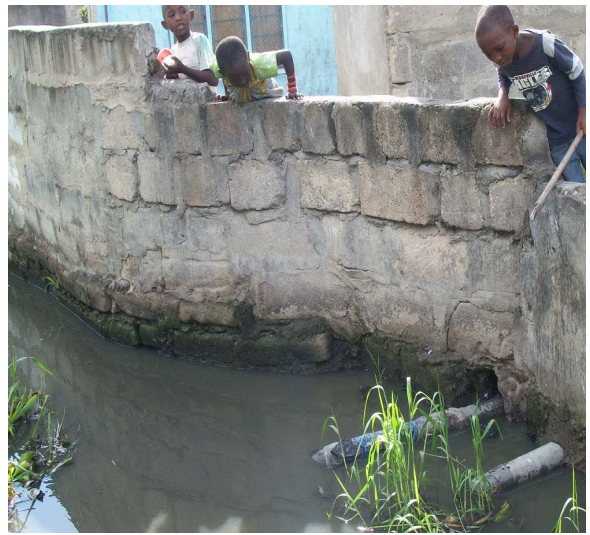

(b)

Figure 1. Sanitation conditions in Keko Machungwa. (a) A flooded toilet; (b) Pipes from a pit-latrine directed to a stream.

extended to beneficieries were in the form of construction materials. Both member and non-members of TLO had access to the loan. Anyone who needed such a loan for improving a toilet was supposed to apply through the Local Authority. The amount of loan paid (in terms of construction materials) ranged from Tshs 200,000 to Tshs 660,000 . The loan was required to be repaid within 18 months at a rate of $10 \%$ and $15 \%$ for members and non-members respectively.

This study revealed slight improvements on sanitation. At the time when this study was being conducted, TLO had managed to construct 35 toilets through the PHAST program. Of the 35 toilets constructed, 33 were households toilets and $2^{9}$ were public toilets. Comparing with the existing number of traditional pit latrines (492) in Keko Machungwa, the 33 toilets constructed could hardly have an impact on sanitation improvement at community level.

\subsubsection{Other Efforts Made on Improved Sanitation, Latrines in Particular}

As reported by UCLAS (2004), about 4\% of the Dar es Salaam population is served by an existing central sewerage system. This indicates that a large number of people especially those in the informal settlements, use other sanitation alternatives. Available research information (Sakijege, Lupala, \& Sheuya, 2012) has revealed that, the most preferred sanitation alternative is to discharge raw waste directly into the storm water and river streams during rainfall. The practice of discharging raw waste into the storm water and river streams is unacceptable and increases health risks. To minimize this problem, TLO introduced pit empting services using a gulper technology. Pit empting service is provided at a cost of Tanzanian Shillings (Tshs) 30,000 per truck with the capacity of 350 liters $\left(0.35 \mathrm{~m}^{3}\right)$. This means that the empting service using gulper technology costs Tshs 85,714 per $^{3}$. During data collection, 2 respondents reported to use the pit empting services by TLO. A total of 15 respondents never used the service as they considered it expensive. While 9 respondents were of the view

\footnotetext{
${ }^{9} 1$ toilet has been built at the Keko Machungwa Market and another one at Keko youth centre.
} 
that living in informal settlement does not require formal practices, 4 respondents were completely unaware of the pit emptig service.

In a discussion with a respondent engaged in pit empting business using cesspit emptier trucks it was revealed that the cost per $\mathrm{m}^{3}$ is Tshs 25,000 . The cost of pit empting using gulper technology (i.e. 85,714 per $\mathrm{m}^{3}$ ) is 3.4 times the cost of cesspit emptier truck (i.e. 25,000 per $\mathrm{m}^{3}$ ). Although such attempts have been made to improve sanitation conditions in Keko Machungwa informal settlement, the cost charged is too high compared to the price charged in prevailing market rates. The high cost charged could be one of the reasons why very few respondents use gulper empting services. In an interview with one respondent it was revealed that flooding and poor solid waste management also contributes to the poor sanitary conditions in Keko Machungwa, this finding is similar to the findings by Sakijege et al. (2014) and Kasala (2014). Evans (2005) and WHO (2014) have argued that efforts to improve sanitation need to consider initiatives beyond construction of improved toilets. Such initiatives in informal settlements should include solid waste and flooding management. In a discussion with an executive chairman of Keko Machungwa settlement it was revealed that, solid waste management and flooding are critical issues that require well thought strategies to address. A recent study by Kasala (2014) conducted in Keko Machungwa revealed several solid waste management problems contribute to unsanitary conditions in informal settlements. The problems include: inaccessibility, inadequate community participation, constraints on cost recovery, lack of cooperation, inadequate community participation, unwillingness of local community to participate in waste collection, and reluctance in paying for solid waste collection fees. In a flood risk management study, Sakijege et al. (2014) identifies flooding and high water table as problems contributing to poor sanitation in Keko Machungwa. These findings reaffirm the position that, efforts to improve sanitation need to go beyond construction of toilets and provision of empting services.

\subsubsection{Community Response towards Improved Sanitation}

It has been established that TLO managed to construct about 35 toilets through PHAST program in Keko Machungwa. That number of improved toilets is very low compared to existing traditional pit latrines (492) in the settlement. The fact that toilets are improved through a loan which is granted upon application by individual residents, the small number of improved toilets implies low community response towards improved toilets. This is contributed to by laxity in implementing current sanitation laws. As a result the construction of improved toilets is considered as optional/nonmandatory.

Regarding technology, it was established that the main technologies used for improving latrine are ecologi$\mathrm{cal}^{10}$ sanitation (ecosan) and pour flush toilets (see Figure 2). Out of 35 improved toilets, only few (2) have been built using ecological sanitation technology. This implies that community response towards ecological sanitation is very low. Interviewed respondents pointed out that, the low response on ecological sanitation is related to the fact that people are not used to such types of toilets.

\subsection{Maguruwe Informal Settlement}

\subsubsection{Existing Latrine Types}

In principle the types of latrines in Maguruwe settlement are not different from the ones found in Keko Machungwa. Considering the 30 respondents interviewed and observations made, the following were revealed in terms of latrine type ownership. About 24 respondents had traditional pit latrine, 3 had pour flash direct pit and 2 had septic tanks. This implies that majority respondents equivalent to (83.3\%) had traditional pit latrines (Table 3).

\subsubsection{Initiatives and Extent to Increase Access to Improved Sanitation (Latrine)}

One of the respondents interviewed explained about existing initiatives to improve latrinesin Maguruwe settlement: He noted: "Our local leaders have been advising us to build proper latrines to reduce health risks". Apart from the encouragement from local leaders, there are no organised initiatives to increase access to improved sanitation in Maguruwe. Available initiatives are mainly individual and on isolated cases. This was reported by about (27) respondents in the course of data collection. An assessment of the existing situation shows that, the question of having improved sanitation (latrine) is not given the attention it deserves and it is not a priority to

\footnotetext{
${ }^{10}$ Ecological sanitation is a form of sanitation that usually involves urine diversion and the recycling of water and nutrients contained within human wastes back into the local environment (http://en.wikipedia.org/wiki/Ecological_sanitation).
} 


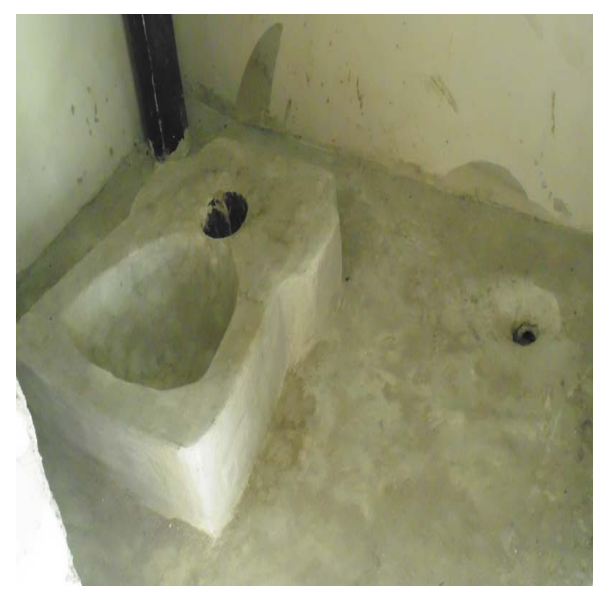

(a)

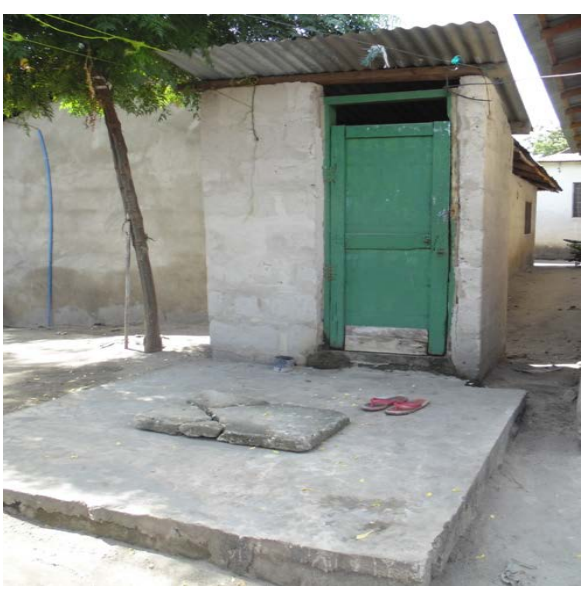

(b)

Figure 2. Types of toilets constructed by Tumaini Letu Organisation. (a) Ecosan; (b) Pour flush toilets.

Table 3. Latrine types of the interviewed household, Maguruwe.

\begin{tabular}{cccc}
\hline s/no & Type of toilets & Number of toilets & Percentage \\
\hline 1 & Traditional pit latrine & 25 & 83.3 \\
2 & Pour flash direct pit & 3 & 10 \\
3 & Septic tank & 2 & 6.7 \\
& Total & 30 & 100 \\
\hline
\end{tabular}

majority residents in Maguruwe settlement. Regarding latrine conditions, the current research has established that about 22 respondents poses toilets that were in poor conditions and were being used by between 2 and 4 household of about 5 members each (Figure 3). The poor condition of toilets is an indication that they are over used and require immediate intervention.

\subsubsection{Other Efforts Made on Improved Sanitation, Latrines in Particular}

Responding to a question about the challenges facing their settlement and initiatives made if any, a respondent noted that "residents in this settlement are inadequately informed and involved in proper sanitation practices. This has led to failures of sanitation related initiatives in Maguruwe”. Previous efforts to minimize the problem of solid waste in Maguruwe provide the best examples for the case in point. As part of existing dangerous sanitation practices also, residents were reported to discharge raw waste into storm water, which normally tend to flood the settlement during rainfall. This practice was reported to create discomfort among community members to the extent that, some consider moving away from the settlement to avoid the wrath of bad adour whe it rains. The efforts to improve sanitation as explained above, show that Maguruwe settlement has other problems of poor solid waste management and flooding. The existence of these problems worsens the already poor sanitation conditions in Maguruwe informal settlement. About 17 of interviewed respondents were of the view that poor solid waste management contributes significantly to unsanitary conditions in Maguruwe settlement. While 11 of the interviewed respondents identified flooding as a problem worsening sanitation conditions in Maguruwe, only 2 respondents reported these problems to contribute to the lack of safe and clean water.

\subsubsection{Community Response towards Having an Improved Sanitation (Latrine)}

"The requirement for better life, proper housing, as well as clean and safe toilet is for all, the poor and rich. Although, life hardships have madeus to be perceived as careless on sanitation related issues, we believe if we get financial support this situation will change at once”. This statement represents the views of many respondents in Maguruwe settlement. A total of 28 respondents reported that they would have preferred to have improved latrines. Alongside that, an analysis of survey results showed that, there are factors that contribute to sanitation 


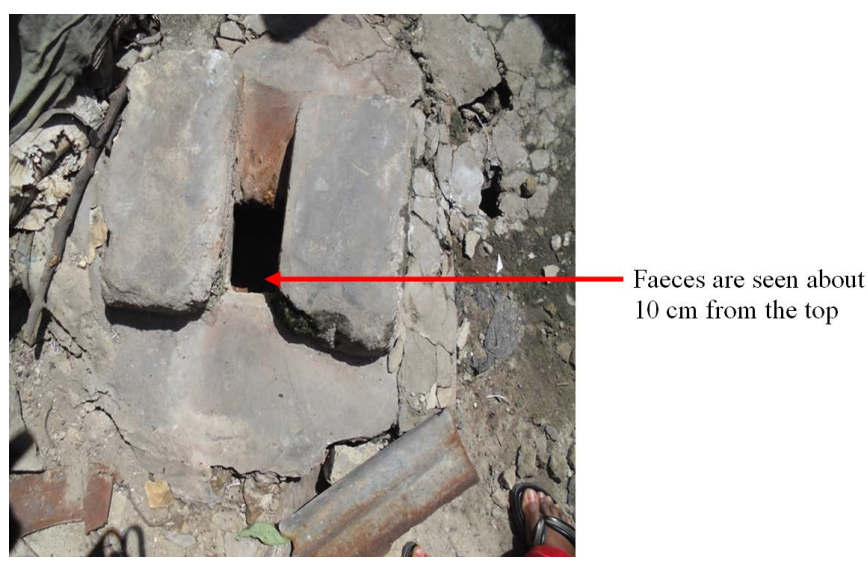

Figure 3. A pit latrine in poor condition, Maguruwe settlement.

malpractices in Maguruwe informal settlement. The factors include: financial constraint, inadequate awareness and cosulted efforts, limited community participation, and laxity on enforcing sanitation related laws.

\section{Cross Case Analysis}

\subsection{Latrine Types}

An analysis of latrine types has shown similarities in the two informal settlements. The most dominant type of latrines used by residents in the two cases is traditional pit latrines ${ }^{11}$. Most of the traditional pit latrines were found to be in poor conditions. In terms of initiatives to improve access to sanitation, Keko Machungwa comes out as a much more advanced case than Maguruwe. The varying situations in terms of improving access to sanitiaon in the two cases are critically analysed in the sections that follow.

\subsection{Initiative to Increase Access to Improved Sanitation}

In both cases poor toilets were perceived as risky to users. However, when initiatives to improve conditions of toilets were examined, the two cases revealed to be different. In Keko Machungwa some initiatives were made to convince residents to improve conditions of toilets. The initiatives as elaborated earlier, were under Tumaini Letu Organisation (TLO). The later's initiatives involved granting a loan to people who wish to improve their toilets. Through the loan facility, for example, a total of 35 toilets were built in Keko Machungwa. Although the number of constructed as improved toilets is small compared to the total (492) number of toilets that are in poor condition, at least an effort has been made. On the other hand, Maguruwe informal settlement doesn't have organised initiatives for improving access to sanitation. The absence of initiatives to improve conditions of toilets in Maguruwe settlement is dangerous and puts the residents' health at risk.

\subsection{Other Initiatives to Improve Sanitation}

In addition to poor latrine conditions, both Keko Machungwa and Maguruwe settlements were found to have problems of poor solid waste management and flooding. All the three ${ }^{12}$ problems were found to significantly contribute to unsanitary conditions. According to Evans (2005), initiatives to improve sanitation have to consider factors beyond latrines. Some of such factors identified were for example solid waste and storm water drainage. The situtation obtaining in both cases revealed weak efforts for managing solid waste and controlling floods as means of improving sanitation and hygiene.

\section{Discussion}

In both cases, poor sanitation is perceived as risk to residents. It was expected that, such perception would inspire residents to construct proper toilets to improve sanitation and hygiene as it was the case in Buguruni

\footnotetext{
${ }^{11}$ Refer to Table 2 and Table 3.

${ }^{12}$ i.e. poor latrine, poor solid waste management and flooding.
} 
Mnyamani informal settlement (Burra, 2011). Construction of proper toilets in Buguruni Mnyamani was possible through a Community Infrastructure Upgrading Program (CIUP). The program faciliated construction of proper toilets through awareness creation and offering technical support. It was also possible through the support of both the rich and the poor living in Buguruni Mnyamani informal settlement. Unfortunately, the situation is different. In Keko Machungwa for example, despite presence of a loan facility for improving toilets and facilitation from TLO and CCI, response was still very low. Compared to the number of toilets (492) that were in poor conditions, only few (35) were improved so far. The situation in Maguruwe settlement is even worse due to the fact that the settlement doesn't have organised initiatives to improve conditions of toilets both at household and community levels. This situation implies that residents in the two settlements are more likely to be affected by infectious disease. This is more likely to happen during rain seasons when raw waste gets discharged directly into nearby river streams and storm water run-off.

The conditions of toilets as revealed in Keko Machungwa and Maguruwe settlement are in conflict with the provision of the Tanzania Water Supply and Sanitation Act No. 12 of 2009. The Act provides that... every person in Tanzania has to have access to effective, efficient, and sustainable sanitation services... The poor toilet conditions found in the two cases, reaffirm the views aired by (Hutton, Haller, \& Bartram, 2007), and Sakijege et al. (2014) and other scholars that, sanitation provision in Dar es Salaam and in other cities of developing countries is deficient.

A thorough analysis of the techniques used to improve conditions of toilets reveals that a combination of two factors namely: influence from the local community groups $s^{13}$ and availability of a loan facility, are the major factors which determine whether or not to improve toilets, the situation is relatively the same in the two settlements. The presence of Tumaini Letu Organisation (TLO) in Keko Machungwa serving as a community influence group, availability of financial support from CCI and monthly contributions from TLO members contributed to improvement on sanitation conditions in Keko Machungwa. The ongoing coordinated improvement of sanitation (latrine) in Keko Machungwa, although is taking place at a small scale, cannot be compared to the situation in Maguruwe settlement. Conditions of toilets in Maguruwe are relatively poor compared to those in Keko Machungwa due to the fact that Maguruwe residents neither have a loan facility to fund sanitation improvements nor had awareness creation campaigns conducted to enlighten them on sanitation issues.

Analysis of the cost of Tshs 85,714 per $\mathrm{m}^{3}$ charged for pit empting using gulper technology as revealed in Keko Machungwa indicates that the cost charged is 3.4 times the cost of using the cesspit emptier truck option. This indicates that use of gulper technology is expensive and thus majority poor people living in informal settlement can't afford it. The findings of this study are not similar to the findings by Boot (2007) in Aceh, Indonesia. Boot (2007) observed that the cost of using Gulper technology for pit empting is slightly cheaper than the cost of using other technologies. It should be noted that the demand for pit empting services in informal settlements is high. It is high in the sense that pit latrines get full regularly. This considers the fact that most informal settlements are situated in low-lying areas that have high water table and are frequently flooded during rainfall. Sakijege et al. (2014). In that regard, the pit empting cost charged for using a gulper technology in Keko Machungwa need to be re-examined if improvement on access to sanitation are real desired.

Evans (2005) and WHO (2014) argue that sanitation is a broad concept that covers issues beyond latrines. This indicates that when efforts to improve conditions of latrine are made, improvements should also be directed to other aspects that have impact on sanitation conditions of a given settlement. The analysis of sanitation situations obtaining in the two cases reveals that, there were no concrete measures in place to ensure that the other issues ${ }^{14}$ contributing to unsanitary condition in the settlements are addressed.

The major limitation to this study was the tendency by respondents to treat certain information as confidential. Respondents were reluctant to diclose their loan spendig details, and were not clear in terms of reasons for not turning up to apply for toilet improvement loan. In this regard, future research has to focus on traits and factors underlying informal settlements residents' resisitance to change.

\section{Conclusions and Recommendations}

This paper has revealed that many developing countries have failed to ensure that at least $50 \%$ of their popula-

\footnotetext{
${ }^{13}$ Local community group which is referred to here is Tumaini Letu Organisation. The Organisation has encouraged and educated residents on proper sanitation practices.

${ }^{14}$ Example of issues referred to here are solid waste and flooding management, among others.
} 
tion get access to improved sanitation as per provisions of the Millennium Development Goal 7, Target 10. The goal was intended to halve, by 2015, the proportion of people without sustainable access to safe drinking water and basic sanitation. Further, this study reaffirms that sanitation conditions are in their worst forms in informal settlements and need immediate consulted interventions. It has been revealed that community based organisations like Tumaini Letu in Keko Machungwa have a significant contribution in educating the local community on issues touching their lives. Improving access to sanitation is one of such issues.

The existence of community groups or organisations for dealing with sanitations issues as it is the in Keko Machungwa, provides a fertile ground for improvement of sanitation situations. However, sustainability of such community groups depends also on how the government is engaged in the whole sanitation improvement process. Findings of this study have shown that efforts to improve sanitation conditions in Keko Machunga did not depend on the government; instead, the efforts were dependent on Centre for Community Initiatives (CCI) as a local NGO and Tumaini Letu Organisation (TLO) as a community based group. Given the broad impact of poor sanitation, and the fact that there are some decisions that cannot be made by local NGOs (e.g. law enforcement) the involvement of the government in an effort to improve sanitation conditions is very crucial. This calls for collaborative approaches in improving sanitation conditions. In addition to local groups and the government, other key stakeholders (e.g. private sectors, donors) need to be involved as well.

The presence of an active Community organisation (TLO) in Keko Machnungwa contributed to attracting attention of the local NGO (CCI). As a way forward, sanitation improvement initiatives in Keko Machungwa need to be maintained and enhanced. The success recorded in Keko Machungwa can be replicated to other informal settlements with similar sanitation situations. In addition, if the aim is to improve sanitation conditions for poor people in informal settlements, some new arrangements need to be considered. That is, 1) each informal settlement has to have a community based group or organisation for sensitizing community members to take part in appropriate sanitation practices. 2) Every household in an informal settlement must be an active member of such a community group. The presence of strong and active community groups or organisations will help to strengthen financial capital, and consequently facilitate sanitation improvement efforts.

Loans provided, in a way, contributed to encouraging people to improve the conditions of their toilets. The findings of the study, however, show that, the decision to take a loan for improving toilet conditions depends on willingness of individual household. This implies that the responsibility to ensure every citizen get effective, efficient, and sustainable sanitation services is in the hands of individual households themselves and that authorities have forsaken their responsibilities. This is against the provisions of the Tanzania Water Supply and Sanitation Act No. 12 of 2009. 3) There is a need to make sure that improvement of latrine and sanitation in general is managed and enforced by responsible authorities. This is in addition to efforts by community groups. Local authorities need to monitor sanitation conditions in different settlements and devise standards to hold responsible the households with poor latrines.

An effort to improve conditions of toilets is one of the ways of improving sanitation. In order to help communities live in an environment that meets health standards, sanitation initiative should not focus on latrines alone. They should go beyond that to include improving access to safe and clean water, solid waste management and flood mitigation measures.

\section{Acknowledgements}

The authors wish to thank all those whose support contributed to the production of this paper. Included in the list are: Local leaders and residents in Keko Machungwa and Maguruwe informal settlements, Field assistants represented by Mr. William Kasyegeta and Reginald Tesha, and Public health staff in Temeke Municipality. Equally important are financial and logistical support from Conreeb Company LTD which was instrumental in accomplishing this research.

\section{References}

Bengoechea, V. (2013). Ghana-GH-GAMA Sanitation and Water Project: P119063-Implementation Status Results Report: Sequence 01. Washington DC: World Bank. http://documents.worldbank.org/curated/en/2013/12/18698417/ghana-gh-gama-sanitation-water-project-p119063-impleme ntation-status-results-report-sequence-01

Boot, N. L.D. (2007). Talking Crap. M.Sc. Thesis, Loughborough: Loughborough University. 
Dubovyk, O., Sliuzas, R., \& Flacke, J. (2010). Spatial-Temporal Analysis of Informal Settlements Development: A Case Study in Istanbul, Turkey. Conference Proceeding of EARSeL Joint SIG Workshop: Urban 3D Radar Thermal Remote Sensing and Developing Countries, At Ghent.

Ecology’s Water Quality Program (2005) Focus on Fecal Coliform Bacteria, Washington State Department of Ecology. https://fortress.wa.gov/ecy/publications/publications/0210010.pdf

Evans, B. (2005). Securing Sanitation: The Compelling Case to Address the Crisis. Report Produced by the Stockholm International Water Institute (SIWI). In Collaboration with the World Health Organization (WHO) Commissioned by the Government of Norway as Input to the Commission on Sustainable Development.

Ghafur, S. (2001). Beyond Homemaking: The Role of Slum Improvement in Home Based Income Generation in Bangladesh. Third World Planning Review. http://dx.doi.org/10.3828/twpr.23.2.e03v811p83432851

Hutton, G., Haller, L., \& Bartram, J. (2007). Economic and Health Effects of Increasing Coverage of Low Cost Household Drinking-Water Supply and Sanitation Interventions to Countries Off-Track to Meet MDG Target 10. Geneva: World Health Organization. http://www.irc.nl/page/38443

Kasala, S. E. (2014). Critical Analysis of the Challenges of Solid Waste Management Initiatives in Keko Machungwa Informal Settlement, Dar es Salaam. Journal of Environmental Protection, 5, 1064-1074. http://dx.doi.org/10.4236/jep.2014.512105

Kibue, S. N. (2007). Shelter and Public Space Needs in Informal Settlements. Paper Presented at World Social Forum, Nairobi, 22 January 2007.

http://www.zoneassociation.org/it/progetti/concorsi/56--shelter-and-public-space-needs-in-informal-settlements-in-nairobi

Kimani, E. W., \& Ngindu, A. M. (2007). Quality of Water the Slum Dwellers Use: The Case of a Kenyan Slum. Journal of Urban Health, 84, 829-838. http://dx.doi.org/10.1007/s11524-007-9199-X

Kjellen, M. (2006). From Public Pipes to Private Hands: Water Access and Distribution in Dar es Salaam Tanzania. Stockholm: Stockholm University.

Kyessi, A., \& Sakijege, T. (2013). Formalizing Property Rights in Informal Settlements and Its Implications on Poverty Reduction: The Case of Dar es Salaam, Tanzania. Preceedings of the Annual World Bank Conference on Land and Poverty, The World Bank, Washington DC, 8-11 April 2013.

Okonkwo, J. O. (2010). Sanitation, Potable Water Supply and Environmental Protection Benefits. Progress and Issues for Sustainability in Developing Countries. AISA Policy Brief No. 23.

Sakijege, T., Lupala, J., \& Sheuya, S. (2012). Flooding, Flood Risks and Coping Strategies in Urban Informal Residential Areas: The Case of Keko Machungwa, Dar es Salaam, Tanzania. Jamba: Journal of Disaster Risk Studies, 4, 10 p.

Sakijege, T., Sartohadi, J., Marfai, M. A., Kassenga, G., \& Kasala, E. S. (2014). Government and Community Involvement in Environmental Protection and Flood Risk Management: Lessons from Keko Machungwa, Dar es Salaam, Tanzania. Journal of Environmental Protection, 5, 760-771. http://dx.doi.org/10.4236/jep.2014.59078

Sheuya, S. (2004). Housing Transformations and Urban Livelihoods in Informal Settlements. The Case of Dar es Salaam, Tanzania. PhD Thesis, Dortmund: University of Dortmund.

Sinai, I. (1998). Using the Home for Income-Generation: The Case of Kumasi, Ghana. Cities, 15, 417-427. http://dx.doi.org/10.1016/S0264-2751(98)00037-7

UNDP (2006). Human Development Report 2006. Beyond Scarcity: Power, Poverty and the Global Water Crisis. New York: United Nations Development Program. http://dx.doi.org/10.18356/334c604b-en

UN-Habitat (2009). Planning for Sustainable Cities: Global Report on Human Settlements. United Nations Human Settlements Programme, London: Earthscan.

UN-Habitat (2013). Global Sanitation Fund Programme in Nepal, Progress Report, SACOSAN-V Special. http://www.unhabitat.org.np/GSF_Nepal_Progress_Report_oct2013.pdf

UNICEF/WHO (2012). Progress on Drinking Water and Sanitation: 2012 Update. New York: UNICEF/WHO.

UNICEF/WHO (2009). Diarrhoea: Why Children Are Still Dying and What Can Be Done. New York: The United Nations Children's Fund (UNICEF)/World Health Organization (WHO).

http://www.unicef.org/health/files/Final Diarrhoea Report October 2009 final.pdf

United Republic of Tanzania (2009). Ministry of Water and Irrigation, Water Sector Status Report 2009. Dar es Salaam: Project Management Office, Mimistry of Water.

United Republic of Tanzania-URT (2013). Population and Housing Census, Population Distribution by Administrative Areas, National Bureau of Statistics, Ministry of Finance Dar es Salaam and Office of Chief Government Statistician President's Office, Finance, Economy and Development Planning Zanzibar. Dar es Salaam: Government Printers.

University College of Lands and Architectural Studies-UCLAS (2004). An Overview of the Water Supply and Sanitation 
System at Metropolitan and Peri-Urban Level: The Case of Dar es Salaam, Draft Report. Dar es salaam: Office of Research and Publication, Department of Environmental Engneering.

WHO (2014). Health Topics. http://www.who.int/topics/sanitation/en/ 